\title{
Dynamics of Maritime Piracy in Southeast Asian Waters: Implications for Fujian Province, China
}

\author{
Kai Chen \\ School of International Relations \\ Xiamen University \\ Xiamen, China
}

\begin{abstract}
This article discusses the dynamics of the maritime piracy in Southeast Asian waters (especially the Straits of Malacca and Singapore), and stresses the implications for Fujian Province, China. The findings indicate that there are three weak points in the security governance of maritime piracy, that is, disputes of the littoral states' sovereignty, limited resources of security governance in Southeast Asian waters, and insufficient information sharing between the littoral countries. Fujian Province plays an important role in China's Maritime Silk Road, for which it has two options in the foreseeable future, that is the Melaka Gateway Project and Kra Canal Project.
\end{abstract}

Keywords-maritime piracy; Southeast Asia; Fujian Province; China; alternative solution

\section{INTRODUCTION}

Many people often assume that the worst-hit area of maritime piracy is Somalia. However, the real hot spot of maritime piracy is the Straits of Malacca and Singapore in Southeast Asia. Today, the Southeast Asian waters are reclaiming their status as one of the most dangerous waters in the world.

The Southeast Asian waters suffered 41 percent of the world's maritime piracy incidents between 1995 and 2013, while the West Indian Ocean (including Somalia), accounted for 28 percent of the maritime piracy attacks in the world. According to the International Maritime Bureau (IMB), in 2015, the piracy incidents in Southeast Asian waters accounted for 55 percent of the world's 54 piracy incidents.[1] In all the incidents, the perpetrators were reported to carry firearms.[2]

According to the latest report of ReCAAP (Regional Cooperation Agreement on Combating Piracy and Armed Robbery against Ships in Asia) in 2016, the piracy incidents involving the abduction of crew for ransom off Eastern Sabah and Southern Philippines remain of concern.[3] In 2016, 33 crew members were abducted in the Southeast Asian waters, and then 18 crew members were released, "with ransoms believed to have been paid, while another 15 are still being held in captivity".[4]

Today, the Straits of Malacca and Singapore accommodates one-third of the world's shipping trade, "(with around 50,000 ships per year passing through this vast territory)".[5] For decades, maritime piracy has been an enormous concern for the littoral states bordering the Straits of Malacca and Singapore, port states and flag states, such as China and Southeast Asian countries. To China, most of its trade passes through the Southeast Asian waters, particularly the Straits of Malacca and Singapore, and "so does up to 80 percent of its energy needs".[6] In other words, one of China's most concerns is associated with its increased energy supply and the maritime piracy in the Southeast Asian waters. In the section that follows, this article will overview the actual incidents reported by in 2016, which victimized Chinese vessels.

\section{ACTUAL INCIDENTS REPORTED IN 2016}

According to the quarterly report of ReCAAP, the piracy and armed robbery against Chinese vessels, occurred at the anchorages in the Indonesian and Philippine waters. For example, on May 18, 2016, a Chinese Bulk carrier was at anchor, and pirates boarded the vessel unnoticed. A search was conducted and five coils of mooring ropes (three unusable and two new) were found missing.[7]

On July 16, 2016, a Chinese tanker was at dock, three small motor bancas came alongside the ship with six unidentified persons on board. Three of the pirates boarded the tanker using ropes and hooks, while the others served as look-outs. The group who boarded the ship broke the padlock and security seal of the forepeak store.[8]

Many of the attacks in southeast Asian waters are opportunistic raids by gangs who snatch stores, cash and valuables before making off in small, fast boats. Though smaller in scale, the crimes are a nuisance and drive up insurance premiums.[9]

For the sake of security, the ship masters and crew were "strongly advised to avoid confronting or antagonising the perpetrators, particularly when they are armed".[10] In the following page, the author will analyze the status of Fujian Province in China's Maritime Silk Road.

\section{Status OF FUJIAN PROVINCE IN CHINA's MARITIME SILK ROAD}

Fujian Province is located on the east coast of China. In 1970s, it took the lead in implementing China's opening-up 
policies.[11] In 2015, the GDP of Fujian Province reached nearly $\$ 318$ billion, an annual increase of 11.4 percent. Depending on its surging economy, Fujian Province is among the most popular destinations for the foreign investors.[12] In 2015, there were 356 projects invested by companies from Southeast Asia, with agreed investment of $\$ 1$ billion.[13]

Moreover, Fujian Province has historic links with Southeast Asian countries. For instance, in this province, Quanzhou was considered as the start point of the China's ancient Maritime Silk Road.[14] In addition, Southeast Asia has 12 million people, who can trace their origins back to Fujian Province.[15] For example, around 7.9 million overseas Chinese can trace their roots back to Quanzhou in this province, and more than 90 percent of them are living in Southeast Asian countries.[16] It's evident that Fujian Province has advantages in promoting economic and cultural co-operations with the Southeast Asian countries along China's Maritime Silk Road in the $21^{\text {st }}$ Century. The following is a analysis of the weak points of security governance in the Southeast Asian waters.

\section{WEAK POINTS OF SECURITY GOVERNANCE}

In the case of counter-piracy operations in Somalia, there was a partnership established by the stakeholders, which strengthened the cooperative efforts, including information sharing, joint patrols, as well as cross-border pursuing. As a result, "Somalia 's coastline has not recorded any major attack on a cargo ship since 2012 thanks to anti- piracy operations of naval patrol vessels since around 2008".[17] People have reasons to believe that the withdrawal of international naval patrol vessels from Somalian waters would probably create a security vacuum.

The Straits of Malacca and Singapore are a major international shipping route of long-standing importance. Since 2004, there has been a regular patrolling operation developed to respond to the maritime piracy in the Straits of Malacca and Singapore, in the form of the Malacca Straits Patrols (MSP).[18] As one of the "most successful multilateral joint maritime operations ever conducted", this operation has reportedly reduced the number of maritime piracy attacks in the Malacca Straits.[19] However, according to Tim Wilkins at the International Association of Independent Tanker Owners, "the number of incidents of theft and robbery in the Straits of Malacca and Singapore may not be as low as reported. Some ship operators may not report crimes as it could take a day or two for investigations, potentially costing them and their customers revenue".[20] In the Straits of Malacca and Singapore, the pirates hijacked the Singapore-registered tanker MT Joaquim in 2016. The tanker was abandoned after the pirates escaped with fuel worth \$700,000.[21]

In the opinion of the author, due to three weak points of the security governance in the Southeast Asian waters, the security governance of maritime piracy is ineffective to a large degree.

First, the disputes of littoral state sovereignty. For example, the bilateral disputes over the territories adjacent to the Straits of Malacca and Singapore always posed difficulties for the joint patrol operations. For instance, the territorial dispute between Indonesia and Malaysia over the resource-rich area of the Ambalat block remained unresolved.[22] As a result, the possibility of any crossboundary patrols, particularly in the event of pursuing maritime pirates in the Straits of Malacca and Singapore, would be very slim.

In October 2015, the Royal Malaysian Navy established a Rapid Deployment Team, in order to tackle maritime privates quickly. This team was composed of two groups, each was staffed by 14 members, and equipped with two helicopters and a gunboat.[23] However, most of the piracy attacks occurred in the territorial waters of the Philippines.[24] The above-mentioned team could not engage in cross-border pursuits of maritime privates in the territorial waters of Indonesia and Singapore, while the pirates zigzagged through the territorial waters of the other littoral countries.

Second, the resources of security governance in Southeast Asian waters were limited. To some degree, the limitation of resources provided by the three littoral countries did contribute to the maritime piracy in the Straits of Malacca and Singapore. Fox instance, due to limited funding, the "Eyes in the Sky" - an aerial surveillance component of the "Malacca Straits Patrols", which "allows aerial patrols to travel over another state's territorial water, proved ineffective as responses to the incidents spotted were slow and unreliable".[25]

Third, the lack of information sharing between the littoral countries. The three littoral countries should have established a hot line to perform real-time tracking of shipments, and given prior notice before the patrolling team chase piracy vessels into other littoral states' territorial waters. In fact, information sharing between the three littoral countries was insufficient. For example, the Malaysia-based International Maritime Bureau and the Singapore-based ReCAAP reportedly "act as rivals rather than working together and providing intelligence coordination”.[26]

\section{IMPLICATIONS FOR FUJIAN PROVINCE}

As far as the author knows, at the very least, there are two alternative solutions for Fujian Province in the foreseeable future. The first solution is Melaka Gateway Project. Recently, China has been trying every efforts to ensure the safe passage of its shipments in the Southeast Asian waters. For example, China invested US\$10 billion (CNY 43.6 billion) in a project named "Melaka Gateway". The Melaka Gateway Project will be due for completion in 2025, which comprises a deep-sea port.[27] It's noteworthy that China invested 43 billion (S\$14 billion) to develop the deep-sea port of the project, which is "expected to be ready by 2019", and "the largest port in the region".[28] In the near future, Fujian Province's shipments would anchor in the deep-sea port of Melaka Gateway Project.

To Fujian Province's shipments, another alternative solution would be the Kra Canal Project in Thailand. The proposed canal was as a Suez-style waterway through 
Thailand's Kra Isthmus at its narrowest point, which would "link the Indian and Pacific Oceans, offering ships a faster route between East Asia, the subcontinent and the Middle East".[29]

If everything goes well, this project could halve the shipping routes between Indian Ocean and South China Sea by more than $1,000 \mathrm{~km}$, by by-passing the threats posed by maritime piracy in Strait of Malacca and Strait of Singapore.[30] All the ships will be requested pay tolls to pass through the canal, and a huge amount of funding will be dedicated towards the security governance of maritime piracy in the Southeast Asian waters. More important, there would be no disputes of state sovereignty in the Kra Canal Project, because Thailand is "accountable for any incidents, security will be high on the government's agenda".[31]

\section{CONCLUSION}

Up to this day, it's still hard for the littoral states to deter maritime piracy in the Southeast Asian waters, particularly the Straits of Malacca and Singapore, let alone responding immediately pirates' robbery, or ensuring prosecution when pirates are caught. In such a case, to China's Fujian Province, there is no optimal solution to ensure the safe passage of its shipments in the Southeast Asian waters. The Melaka Gateway Project and Kra Canal Project might be the alternatives. Further research is required to confirm more alternatives.

\section{ACKNOWLEDGMENT}

The research for this article was financially supported by the Educational Research Grant of Education Department of Fujian Provincial Government for Young and Middle-aged Teachers, Grant No. JAS160004.

\section{REFERENCES}

[1] Anonymous. "How Kra Canal can combat piracy in Straits of Malacca". Nation, The (Thailand). 13 August 2016.

[2] ReCAAP Information Sharing Centre. "ReCAAP ISC Quarterly Report January-September 2016”. http://www.recaap.org/DesktopModules/Bring2mind/DMX/Downloa d.aspx?Command=Core_Download\&EntryId=ent460\&Method=attac hment\&PortalId=0\&TabId=78, accessed 1 December 2016

[3] ReCAAP Information Sharing Centre. "ReCAAP ISC Quarterly Report January-September 2016". http://www.recaap.org/DesktopModules/Bring2mind/DMX/Downloa d.aspx ?Command=Core_Download\&EntryId=ent460\&Method=attac hment\&PortalId=0\&TabId=78, accessed 1 December 2016 .

[4] Anonymous. "Top Official Raises Concerns Over Piracy Near Southern Philippines". BBC Monitoring International Reports. 19 September 192016.

[5] Anonymous. "Duterte to Focus on Piracy, Crime During Visit to Kuala Lumpur". Nation, The (Thailand). 8 November 2016.

[6] Teoh, S. "Malacca Harbour Plan Raises Questions about China's Strategic Aims". Straits Times, The (Singapore). 14 November 2016.

[7] ReCAAP Information Sharing Centre. "ReCAAP ISC Quarterly Report January-September 2016”. http://www.recaap.org/DesktopModules/Bring2mind/DMX/Downloa d.aspx?Command=Core_Download \&EntryId=ent460\&Method=attac hment\&PortalId=0\&TabId=78, accessed 1 December 2016 .
[8] ReCAAP Information Sharing Centre. "ReCAAP ISC Quarterly Report January-September 2016". http://www.recaap.org/DesktopModules/Bring2mind/DMX/Downloa d.aspx?Command=Core_Download\&EntryId=ent460\&Method=attac hment\&PortalId=0\&TabId=78, accessed 1 December 2016.

[9] Anonymous. "Piracy makes Malacca straits the world's most dangerous sea." Times [London, England] 1 Sept. 2015: 29. Business Insights: Global. Web. 4 Dec. 2016.

[10] ReCAAP Information Sharing Centre. "ReCAAP ISC Quarterly Report January-September 2016". http://www.recaap.org/DesktopModules/Bring2mind/DMX/Downloa d.aspx?Command=Core_Download $\&$ EntryId=ent460\&Method=attac hment\&PortalId=0\&TabId=78, accessed 1 Dec 2016.

[11] Ye, J. and Hu, M.D. "Manufacturing Leads Fujian's Foreign Trade". China Daily (Beijing, China). 14 April 2015.

[12] Anonymous. "Fujian opens doors to investors". China Daily (Beijing, China). 7 September 2013.

[13] Wang, H. and Hu, M.D. "City Readies Belt and Road Hub Strategy". China Daily (Beijing, China). 18 May 2016.

[14] Hao, N. "Robust trade in maritime Fujian". China Daily (Beijing, China). 15 April 2014.

[15] Anonymous. "China Beckons ASEAN Investors to Fujian”. Bangkok Post (Thailand). 4 July 2015.

[16] $\mathrm{Hu}, \mathrm{M}$. D. and Lu, T. "Fujian on Course to Help Create the New Maritime Silk Road". China Daily (Beijing, China). 9 September 2014.

[17] Anonymous. "Piracy Still A Threat Off Somalia, Says UN". Shabelle Media Network (Mogadishu, Somalia). 18 November 2016.

[18] Anonymous. "Duterte to Focus on Piracy, Crime During Visit to Kuala Lumpur". Nation, The (Thailand). 8 November 2016

[19] Lebang, C. G. and Arif, M. "Joint Patrol: Challenges and Recommendations". Asia News Network (ANN). 28 April 2016.

[20] Koh, J. "Drop in Piracy in Regional Waters: Concerted Enforcement Effort Leads to Just One Case in First Half of Year". Straits Times, The (Singapore). 20 September 2016.

[21] Anonymous. "Piracy Makes Malacca Straits the World's Most Dangerous Sea". Times (London, England). 1 September 2015

[22] Lebang, C. G. and Arif, M. "Joint Patrol: Challenges and Recommendations". Asia News Network (ANN). 28 April 2016.

[23] Anonymous. "Joint Regional Efforts Behind Piracy Drop: Singapore Report”. BBC Monitoring International Reports. 20 September 2016.

[24] Lebang, C. G. and Arif, M. "Joint Patrol: Challenges and Recommendations". Asia News Network (ANN). 28 April 2016.

[25] Anonymous. "How Kra Canal Can Combat Piracy in Straits of Malacca". Nation, The (Thailand). 13 August 2016.

[26] Anonymous. "How Kra Canal Can Combat Piracy in Straits of Malacca". Nation, The (Thailand). 13 August 2016.

[27] Koh, K. "China Help for RM40b Malacca Project". New Straits Times (Kuala Lumpur, Malaysia). 8 November 2015.

[28] Teoh, S. "Malacca Harbour Plan Raises Questions about China's Strategic Aims". Straits Times, The (Singapore). 14 November 2016.

[29] Paul, A. "Kra Canal Project A Never-ending Story". Straits Times, The (Singapore). 27 May 2004.

[30] Isa, M.H. M. "Kra Canal Proposal: Dream or Reality?”, Bernama: The Malaysian National News Agency (Malaysia). 10 July 2016.

[31] Anonymous. "How Kra Canal Can Combat Piracy in Straits of Malacca". Nation, The (Thailand). 13 August 2016. 